\title{
Sorumlu Üretim ve Tüketim Bağlamında Permakültür ve Kentsel Açık ve Yeşil Alan ilişkisi
}

\author{
Arash NAJAFIDASHTAPE*, Cenk HAMAMCIOĞLU \\ Yıldız Teknik Üniversitesi, Mimarlık Fakültesi, Şehir ve Bölge Planlama Bölümü, 34349, İstanbul, Türkiye. \\ *e-mail:arashalon@gmail.com \\ Öz
}

Kentlerde süregelen hızlı nüfus atışı, göç ve şehirleşme doğal dengeyi tehdit eden ve bir o kadar da doğa ile ilişkileri zayıf yaşam biçimleri ve alanları ortaya çıkarmaktadır. Bu süreçte kaynakların verimsiz kullanılması ve aşırı tüketilmesi kentlerin yer aldıkları ekosistemlerin düzenini bozmakta, çevrenin tahrip edilmesinden tarım topraklarının yapılaşmaya açılması sonucu üretimin azalarak diğer bölgelere bağımlılı̆̆ın artmasına, karbon salınımından küresel ve yerel ölçekte iklim değişikliğine kadar birçok konuda sorunların ortaya çıkmasına sebep olmaktadır. Bu gidişat doğal çevre ve kaynaklar açısından kentleri tüketci ve atık üretici yapılı çevrelere dönüştürmektedir. Sorunlar karşısında çevreye olumsuz etkilerin azaltıldığı, kaynakların bilinçli ve verimli değerlendirildiği daha sağlıklı yaşam alanlarının tasarlanması amacı ile son yıllarda doğanın döngüsünü dikkate alan ekolojik sistem temelli yaklaşımlar ve yöntemler geliştirilerek tartışılmakta ve denenmektedir. Insanın doğa ile uyumlu bir çevrede yaşamını sürdürülebilir kılacak ilkeler geliştirmeyi hedefleyen ve kentsel tasarım açısından önemi giderek artan yaklaşımlardan biri de permakültürdür. Çalışma; kentlerde doğanın devamlılığını sağlayan ve toplumun farklı ölçeklerde ihtiyaçlarının karşılandığı açık ve yeşil alanların verimli, üretken, sürdürülebilir tasarımında, permakültür bakış açısının, gerek kent ekolojisine gerekse topluma ve yerel yönetimlere sağlayabileceği katkıları gündeme getirmeyi amaçlamaktadır. Kentsel açık ve yeşil alanların sürdürülebilirlik açısından yetersiz olması, bu alanlarda kullanılan bitki türlerinin işlev ve özelliklerinin göz ardı edilmesi, sulama ve drenaj sistemlerinin enerji ve kaynak kullanımı açısından israfa yol açması ve tasarım elemanları arasında bağlantıların kurulmaması çalışmanın gerekçeleri olmuştur. Buna göre, makalede öncelikle kentsel açık ve yeşil alan düzenlemelerinde genellikle tüketim odaklı gerçekleşen tasarımlar ve ilişkili olduğu diğer sorunlar tanımlanmaktadır. Ardından, literatür özetini içeren permakültür kavramı ve tasarım ilkeleri örneklerle ortaya konulmakta, kentsel alanlardan uygulamalara yer verilmektedir. Elde edilen bilgiler doğrultusunda çalışmada, kentsel açık ve yeşil alanların permakültür ilkeleri ile sorumlu üretim ve tüketim anlayışı çerçevesinde verimli ve etkin tasarımının; yerin doğal özelliklerine uygun, su, enerji gibi kaynakları israf etmeden, atıkları ise kendi sistem döngüsü içinde kullanan dolayısıyla olası afet ve iklim değişikliğine karşı kentlerin direncini destekleyecek, toplumu bilinçlendirici, eğitici, birleştirici, istihdam yaratma gibi pek çok kazanımları değerlendirilmektedir.

Anahtar Kelimeler: Kentsel açık ve yeşil alan, ekolojik tasarım, permakültür, permakültür ilkeleri, permakültür örnekleri

\section{Relevance Between Permaculture and Urban Open and Green Spaces In the Context of Responsible Production and Consumption}

\section{Abstract}

Ongoing rapid population growth, migration and urbanization in cities threaten the natural equilibrium as much as reveal poor lifestyles and facility areas associating weak interactions with nature. In this process; inefficient

Atıf: Najafıdashtape, A., Hamamcıoğlu, C. (2018). Sorumlu Üretim ve Tüketim Bağlamında Permakültür ve Kentsel Açık ve Yeşil Alan İlişkisi. Mimarlık Bilimleri ve Uygulamaları Dergisi (MBUD), 3 (1), 1-17. DOI: $\underline{10.30785 / \mathrm{mbud} .370274}$ 
utilization of resources and excessive consumption disrupt the ecosystems where the cities are located. The destruction of the environment and converting agricultural lands into built environs decrease the production and paradoxically increase dependency on other regions and cause many other problems from carbon emissions to the local and global scales of climate change. But this progress of situation has transformed cities into consuming and waste producing built environments in terms of nature and resources. Against these problems in recent years, ecological system based approaches and methods considering nature's cycle are being developed and discussed, with the aim of designing healthier settlements where adverse effects are reduced, resources are consciously and productively assessed. In terms of urban design, permaculture is one of the increasingly important approaches that aim to develop principles in order to sustain human life harmonious with nature. This research; driven by the need for efficient, productive and sustainable design of open and green spaces that provide the continuity of nature in cities and meet the needs of communities at different scales aims to bring forth the contributions to urban ecology, community and local governments by the permaculture point of view to the agenda. Inadequate design in terms of sustainability, obscuring the functions and properties of plant species, irrigation and drainage systems leading to leakage in terms of energy and resource utilization and lack of links between design elements has become major reasons to on urban open and green areas in this article. Accordingly, the article primarily identifies and focuses on the consumption-oriented design and other issues in the organization of urban open and green spaces. In the context of research, the achievements of efficient and effective design of urban open and green spaces within the framework of permaculture's responsible production and consumption perspective are evaluated. Possible achievements stated at the conclusion are; providing appropriate design to the natural characteristics of a place without consuming vital resources such as water, energy where wastes are utilized in the cycle of the system that will support the resistance of cities against probable disaster and climate change, meanwhile increasing community awareness, training, unification and create job opportunities.

Keywords: Urban open and green space, ecological design, permaculture, permaculture principles, permaculture examples

\section{Giriş}

Açık ve yeşil alanlar gerek birey ve toplumun doğa ile ilişkisi gerekse de doğanın yapılaşmış çevre içindeki sürekliliği bakımından kentlerin temel arazi kullanımlarından birisidir. Kentlerin ekolojik, fiziksel, sosyal ve ekonomik yapısının biçimlenmesinde rol oynayan bu alanlar, toplumun yaşam kalitesi ve kamu yararı üzerinde de önemli etkilere sahiptir. Kentsel açık ve yeşil alanlar yapılaşmış çevre dışında kalan, toprak yüzeyi ve bitki örtüsünün bulunduğu, kamusal ya da özel mülkiyete ait peyzaj alanlarıdır (Aydemir, 2004). Konut bahçeleri, çocuk oyun alanları, mahalle ve semt parkları, mezarlıklar, botanik bahçeler, sergi ve fuar alanları, gıda üretim alanları gibi işlevleri kapsayan bu tür alanlar dinlenme, oturma, koşma gibi rekreasyon ve spor etkinliklerinin yanında ürün, bitki, ağaç yetiştiriciliği, eğitim gibi pek çok açık alan faaliyetlerinin de yapııdığı alanlardır. Ayrıca, kentsel açık ve yeşil alanlar üstlendikleri işlevler ve alan büyüklükleri ile kentlere hiyerarşik konum, estetik, imaj, karakter, temiz hava, sağlıklı çevre ve toplum, gıda temini gibi birçok değer, işlev ve yararlar kazandırmaktadır (Hopper, 2007; Buchan, 2013).

The World Bank (2017) verilerine göre 1960 yılında dünyada nüfusun \%33,6'sı, Türkiye'de ise \%32'si kentlerde yaşarken, 2016 yılına gelindiğinde aynı oran dünya genelinde \%54,3'e, Türkiye'de ise \%74'e yükselmiştir. Ayrıca Birleşmiş Milletler tahminine göre, 2050 yılına kadar küresel nüfusunun yaklaşık \%66'sının kentlerde yaşayacağı öngörülmektedir (United Nations, 2004). Bu veriler doğrultusunda farklı ekonomik, sosyal faktörler ve göç nedeni ile nüfusun kentlerde yığılma eğilimi, açık ve yeşil alanlar açısından literatürde tartışılan üç temel sorun kümesini gündeme getirdiği görülmektedir. Bunlardan ilki kontrolsüzce büyüyen ve yayılan kentsel alanlarda ekosistemlerin parçaları olan açık ve yeşil alanların baskı altına alınarak yapılaşma riski ile karşı karşıya kalmasıdır (Bhatta, 2010; Mensah, 2014). Bu sorun toplumun artan temel ihtiyaçları ve sağlığı için gereken doğal kaynakları ve ortamları barındıran kentsel açık ve yeşil alanların yetersiz kalması, zarar görmesi ya da kaybedilmesi ile ilişkilidir.

İkinci sorun kümesi ve bu çalışmanın çıkış noktasını oluşturan konu ise kentsel açık ve yeşil alanların sürdürülebilir olmayan yöntemlerle tasarlanmasının dolaylı ya da doğrudan doğal kaynaklar ve kent üzerinde yarattığı olumsuz etkiler ve üretken özelliğinin yitirilmesine odaklanmaktadır (Hall, 2011; Magigi, 2013; Zeeuw ve Drechsel, 2015). Kentsel açık ve yeşil alanlar her ne kadar ulaşım, konut, 
sanayi alanlarındaki gibi doğrudan kirletici etkide bulunmasa da, verimsiz tasarlandığında tüketici durumuna gelerek; enerji, su gibi kaynakların gereğinden fazla kullanıldığı ya da atık üretici alanlara dönüşebilmektedir. Bu bağlamda örneğin; yerel iklime ve peyzaja uygun olmayan, çok su gerektiren bitkilerin seçilmesi veya mevsimlik bitki dikiminin sürekli yenilenmesi, destekleyici müdahalelerle kendi içinde gerçekleşecek döngünün sağlanmasına izin verilmemesi önemli miktarda su ve yerel sermayenin israfına, ayrıca atık üretimine neden olmaktadır. Ya da sert zemin oranının fazla olması durumunda açığa çıkan ısı adası etkisi bitki ve ağaç gibi yeşil elemanların sağladığı serinletici etkiyi ortadan kaldırmakta, kentsel açık ve yeşil alanların mikroklimayı düzenleyici özelliği mümkün olamamaktadır.

Üçüncü sorun kümesi ise, kaynaklarının üçte ikisinden fazlasının tüketilmekte olduğu kentlerde yukarıda bahsedilen iki temel sorun ve diğer kentsel arazi kullanımların neden olduğu olumsuz etkiler sonucunda enerji, su, gıda gibi temel ihtiyaçların karşılanmasında yetersiz kalınarak dışa (diğer yöre ya da bölgelere) bağımlılığın artmasıdır. Kentlerde temel ihtiyaçların uzak mesafelerden temin edilme süreci (örneğin gıda ürünlerinin taşımacılığında havayolu ve karayolunun kullanılması, başka bir havzanın yaşam döngüsünü sağlayan akarsuların tutularak kente yönlendirilmesi ya da enerji üretimi için yeni baraj, HES yatırımları ...) karbon salınımı, hava kirliliği, diğer bölgelerdeki doğal ve yerleşme ekosistemlerinin zarar görmesi, sömürülmesi gibi problemlere yol açmaktadır. Bu durum ise kentlerin iklim değişikliği, yıkıcı afetler, çölleşme gibi büyük ölçekli çevre sorunları ile karşı karşıya kalma riskini de yükseltmektedir. Dolayısıyla kuraklık, gıda üretiminde alan ve verim kaybı, açlık ve susuzluk özellikle nüfusu artmakta olan kentlerde giderek daha sık yaşanan sorunlar olarak belirmektedir. Bu bağlamda örneğin 'doğal kaynaklar ve direnç' kategorisinde iklim ile ilgili risklerin gıda sistemleri için uzun vadeli tehditler oluşturduğunun vurgulandığı Küresel Gıda Güvenliği 2017 Endeksi'ne göre Türkiye 113 ülke arasında 49. sırada yer almıştır (Yavuz, 2017). Diğer taraftan dışa bağımlı kentlerde ya da tam tersi ihtiyaçların karşılandığı bölgelerde yaşanacak bir afet, gereksinim duyulan su, enerji gibi kaynakların ya da gıda ürünlerinin erişimini, teminini kısıtlama ihtimali yüksek riskler ortaya koymaktadır. Oysa ki kentlerin geleceği kendi kendilerine yetebilir olmaya bağlıdır. Başka bir deyişle kentlerde yaşanan sorunlara yönelik çözümler yerel sistemin dışında ya da diğer bölgelerde aranmamalıdır. Bu nedenle de kentlerde enerji, kaynak, maliyet ve zaman tasarrufunun yapılabilmesi için sorumlu yerel üretim ve tüketim anlayışının, buna yönelik de kent planlamada arazi kullanım kararları ve tasarım ilkelerinin geliştirilmesine yardımcı olacak yaklaşımlar önem kazanmaktadır.

Tüm bu sorunlar ya da yaşanması çok muhtemel koşullar sürecinde azalan doğal alanlar, kötü yaşam şartları, artan gıda ihtiyacı, su israfı gibi konular kentsel işlev alanlarından biri olan açık ve yeşil alanların verimli tasarımını gerekli kılmaktadır. Özellikle 1980'lerin ikinci yarısından buyana kent ölçeğinde ekokent, yeşil kent gibi yaklaşımlar, daha alt ölçeklerde ise çatı bahçesi, pasif güneş enerji sistemleri, yeniden bitkilendirme (revegetation) gibi ekoloji odaklı tasarım yaklaşımları tartışılmaktadır. Bu çalışmada ise kentsel açık ve yeşil alanların tasarımında kent, doğa ve üretimin bütünleştirilerek değerlendirilebileceği, sistem ekolojisine temellenen permakültür yaklaşımına odaklanılmıştır. Çalışma ile öncelikle amaçlanan, kendi kendine yetebilen sürdürülebilir sistemlerin geliştirilmesini savunan permakültür kavramının ve bakış açısının ortaya konulmasıdır. Çalışmanın diğer amacı ise; kentsel açık ve yeşil alanların sağlıklı ve doğa ile uyumlu tekniklerle tasarımını ve bu tür alanlarda sürdürülebilir tarımı destekleyecek permakültür yaklaşımının önemini vurgulamaktır.

\section{Materyal ve Yöntem}

Bu bölümde giriş bölümünde açıklanan sorun tanımlama ve çalışma konusuna bağlı olarak araştırma sürecinde izlenen yöntem açıklanmaktadır. Çalışmanın kapsamını oluşturan ana materyal permakültür kavramının araştırılması ve kentsel açık ve yeşil alanlar ile ilişkisidir. Konuya ilişkin temel kaynaklar araştırılmış ve incelenmiştir. Elde edilen bulgular doğrultusunda permakültür kavramına ile ilgili literatür özeti hazırlanmış ve uygulama örnekleri incelenmiştir.

Yöntem olarak permakültür kavramı, etikleri, tasarım ilkeleri ve aşamalarına yönelik temel kaynakların araştırıımasını içeren uluslararası ve ulusal literatür taraması yapılmıştır. Yöntemin bu aşamasında özellikle permakültür kavramını literatürde ilk kez ortaya koyan Mollison (1979, 1981, 2017) ve Holmgren (2001)'in yanısıra Hemenway (2009), Hahn (2014) ve Rothe (2014)'in 
kaynaklarında ortaya konulan tanımlamalar, ilkeler, sınıflandırma ve örnek şekillerden yararlanılmıştır. Daha sonra belirtilen kaynaklardan ve permakültür tasarımı ile ilgili yabancı WEB siteleri incelenerek uygulama örnekleri incelenmiştir. Kentsel alanlarda gerçekleştirilen permakültür örneklerinden dördü seçilerek, kısaca, uygulamalar hakkında bilgi verilmiştir. Giriş bölümünde açıklanan sorun tanımlaması gözönünde bulundurularak, kavram ve örnek araştırması ile elde edilen bulgular sonucunda, permakültür ve tasarım yaklaşımının kentsel açık ve yeşil alanlar açısından önemi ve katkıları maddelerle ifade edilmiştir. Çalışma sonunda, kentsel açık ve yeşil alanların permakültür ilkeleri ile sorumlu üretim ve tüketim anlayışı çerçevesinde verimli ve etkin tasarımının kentsel açık ve yeşil alanlar açısından sağlayacağı girdilerin yanı sıra kente, topluma ve yerel yöntemlere kazandıracakları tartışılmaktadır.

\section{Araştırma Bulguları}

\subsection{Permakültür Kavramı}

Permakültür, ilk kez 1970 'li yıllarda Avustralya'da Mollison ve Holmgren'in çalışmalarıyla gündeme gelmiştir. Permakültür; ekosistemin sorunlarına karşı geleneksel tarım yöntemlerini, bilimsel bilgiyi, teknolojiyi ve beceriyi harmanlayarak bütüncül çözümlerin geliştirildiği insan yerleşimlerini tasarlayan bir yer bilimi olarak ortaya çıkmıştır (URL-1, Althouse, 2016). İnsan faaliyetlerinin çevreye ve insana verdiği zararlara karşı toplumda artmaya başlayan bilinçlenme sürecinde literatüre girmiş olan permakültür bilim alanının içerdiği yöntemler, şekil 1'de belirtilen kalıcı tarım, toprak verimliliği, doğal tarım felsefesi, farklı ağaç ve bitki sistemlerinde yapılan deneyler gibi daha önceki yaklaşımlar temel alınarak geliştirilmiştir. Permakültürün (permaculture) kalıcı tarım (permanent agriculture) ve kalıcı kültür (permanent culture) terimlerinden meydana geldiğini açıklayan Rothe (2014), anlam karşılı̆̆ını "insan yaşamı ve kültürünün devamlılı̆ı̆” olarak ifade etmektedir. Mollison (2017)'a göre permakültür; doğal sistemlerin gözlemlenerek zengin ve sürdürülebilir insan yerleşimlerinin oluşturulduğu bir tasarım yöntemidir. Holmgren (2001)'e göre ise permakültür; yerel ihtiyaçların karşılanması, kaynakların sağlıklı tüketilmesi için sürdürülebilir yerleşim alanları ve gıda üretim sistemlerinin uygulandı̆̆ı bir peyzaj tasarımıdır.

Permakültür kurduğu ilişkiler zinciri ile yaşamın bütününü kapsayan bir yaşam felsefesi ortaya koymaktadır. Başka bir ifade ile permakültür doğaya karşı gelmekten ziyade, doğa ile eşgüdümlü çalışma, uzun süreli ve özenli gözlem yaparak sistemin tüm parçalarını dikkate alma ve kendi döngüsüne izin verme felsefesini içeren bir tür ekolojik tasarım yöntemidir. Bu tasarım yöntemi, canlı türlerinin çevreleri ile nasıl uyum sağladıkları ve doğada oluşturdukları uyumun nasıl bir düzene sahip olduğunu incelemektedir.

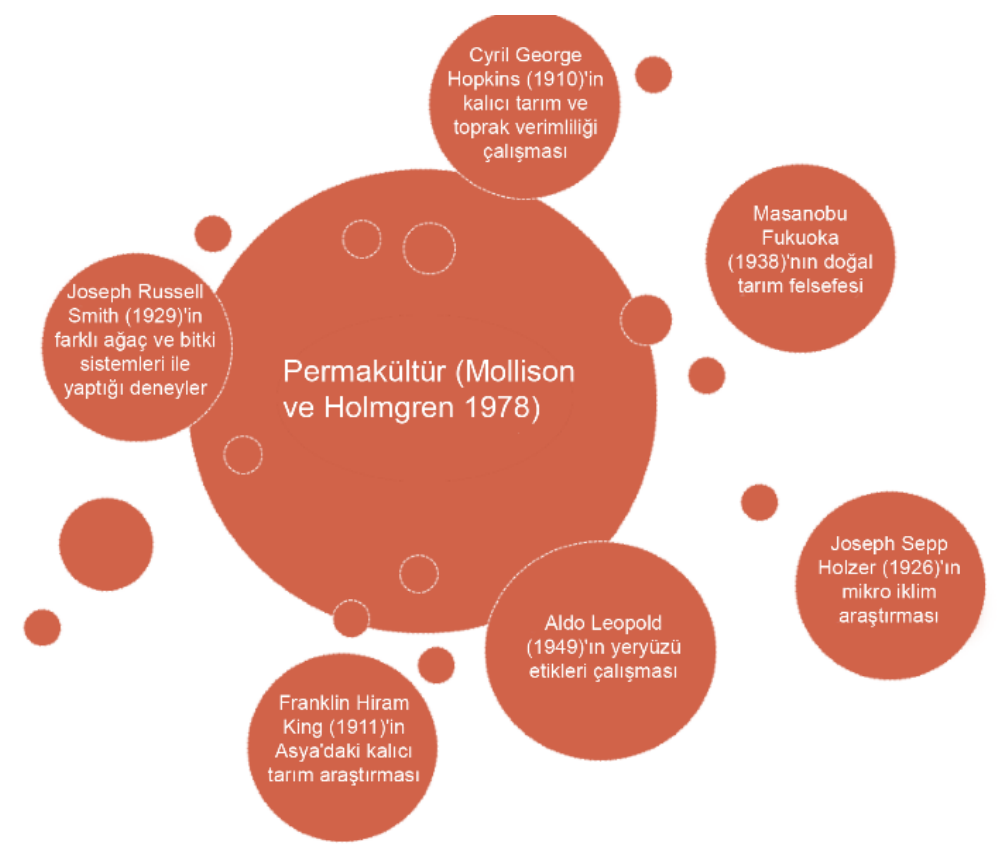

Şekil 1. Permakültür gelişim şeması (Mabalay Flores ve Bosita Mendiola, 2016) 
Mollison (1979), permakültür sayesinde yiyecek üretimini kentsel alanlara geri getirmeyi amaçlamaktadır. Bu doğrultuda permakültür, sürdürülebilir politikalar yaratmak için kentlerde de uygulanabilecek ilke ve örnekler içeren pratik, yaratıcı ve uygun (pozitif) bir tasarım yöntemi sunabilmektedir. Benzer bakış açısına sahip Hemenway (2009)'e göre ise permakültür; sağlıklı besin, temiz su, yenilenebilir enerji ve doğal yaşam alanı yaratma gibi toplumun kentsel ihtiyaçlarını sürdürülebilir ve esnek yollarla karşılanma konularını ortaya koymaktadır. Bu tasarım yöntemi doğal ekosistem içerisinde insanı tüketici olma konumundan, üretici konumuna getirmektedir. Bu süreçte permakültür tasarımının hedefi, doğaya zarar vermeden sağlıklı gıda ve enerji bakımından doğaya uygun, kendi içinde döngüsü olan ve yetebilen, atık üretmeyen su, toprak, hava, bitki ve ağaç, insantoplum, hayvan gibi yaşamın tüm taraflarına faydalı ilişkiler kurarak bütünleştiren bir sistemin oluşturulmasıdır.

Permakültür, ortaya koyduğu etik ve ilkeler ile ana kararların belirlenmesi için tasarımcıya bir tür yol haritası sunmaktadır. Bu etik ve ilkeler insanın yaşadığı ortamla bir tür işbirliği - denge içerisinde ihtiyaçlarını karşılamasını hedeflemektedir. Enerjiyi en verimli şekilde kullanma biçiminden, kendi içinde atıkların değerlendirilmesine, çevrenin doğal yapısına uygun tasarlanması, sağlıklı gıda üretimi, gelir kaynağı sağlama, su kaynaklarının tutumlu kullanılması, enerji tasarrufuna kadar birçok konuda tasarım ilkeleri belirleyen permakültür, doğaya uygun ve verimli sistemleri mümkün kılma arayışındadır.

\subsection{Permakültür Etik ve İlkeleri}

Permakültür tasarımı; doğa, insan ve yeryüzündeki diğer canlılar için faydalı olma açısından üç temel etik kuralını içermektedir. Bu etik kurallar hem tasarımı şekillendirmekte hem de alanın hangi değerlere göre ele alınacağı konusunda kaynak ve yol gösterici olmaktadır (Mollison, 1979, Althouse, 2016). Üç etikten oluşan bu kuralların en önemli parçası insandır (Şekil 2), çünkü yapılan her şey insan hayatının daha iyileştirilmesi üzerine kurgulanmaktadır. Bu iyileştirmede de en büyük görev insanoğluna düşmektedir. Yeryüzü, insan ve tüketim ilişkisi üçgeninde bulunan permakültür etikleri, insanın doğayla dengeli ilişkiler kurmasını ve buna uygun yöntemlerle intiyaçlarını karşılamasını amaçlamaktadır. Buna göre;

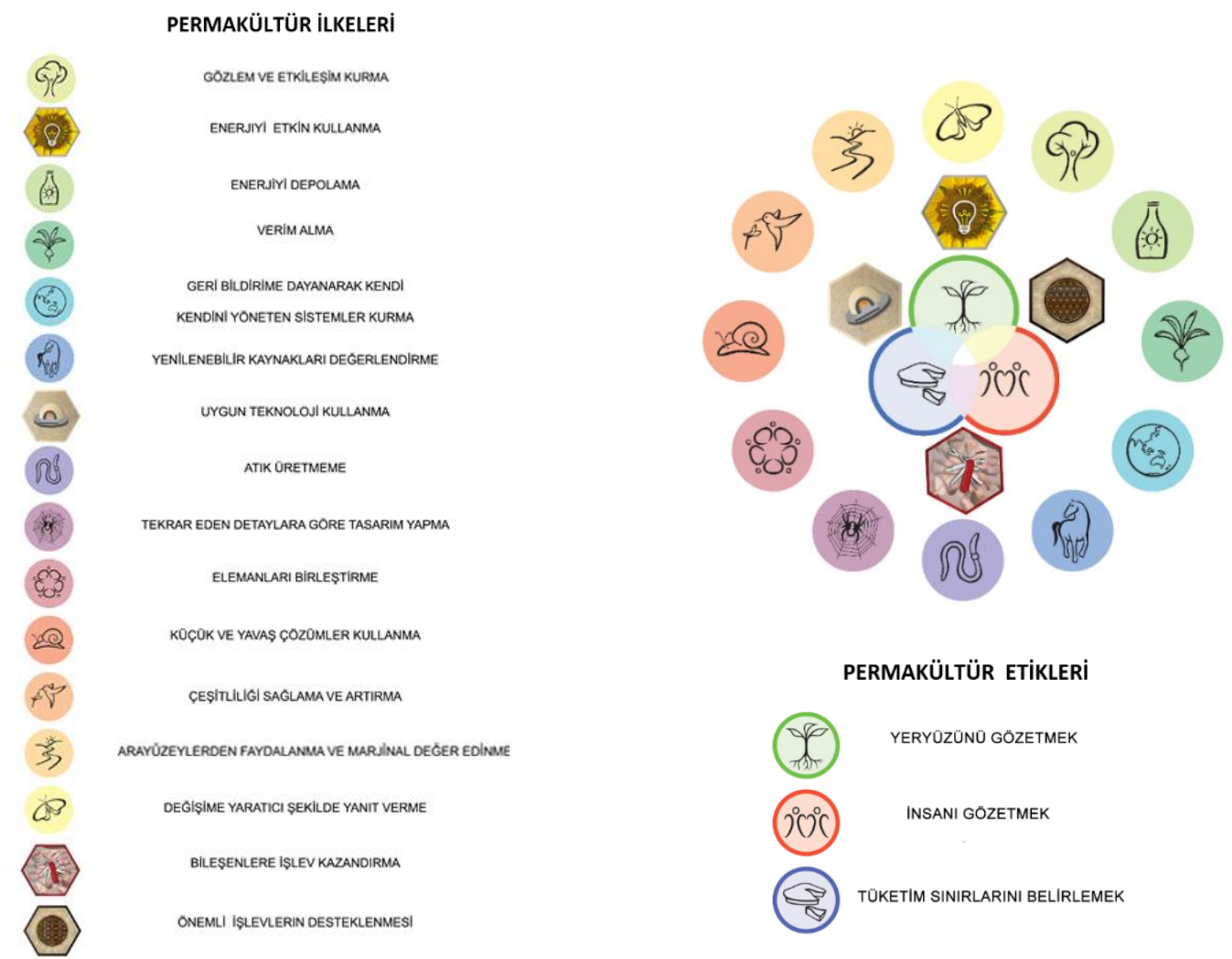

Şekil 2. Holmgren ve Mollison'un permakültür etik ve ilkeleri (Najafidashtape tarafından bir araya getirilerek hazırlanmıştır 
Yeryüzünü gözetmek: İnsanın yaşamını devam ettirdiği alanı ifade eden yeryüzü, korunması gereken ilkelerin başında gelmektedir. Doğal ve uzun ömürlü bir yaşamın sağlanabilmesi için insanların ihtiyaçlarını ekosisteme uyumlu, sürdürülebilir yoldan ve daima iyileştirici şekilde karşılaması gerekmektedir. Bunların bütünü yeryüzüne özen göstermeyi ifade etmektedir.

İnsanı gözetmek: Doğanın yöneticisi konumunda olan insan, verdiği kararlar ve yaptığı faaliyetlerle yeryüzünde belirleyici role sahiptir. Bu roldeki en önemli vazifelerinden biri enerji, gıda, barınak vb. ihtiyaçlarını ve kaynaklara erişimini doğanın düzenini bozmadan, insanın kendisine değer vererek ve geleceğini riske atmadan karşılamasıdır.

Tüketim sınırlarını belirlemek: Doğal kaynaklar kullanılarak sağlanan gıda, enerji gibi birçok ihtiyacın denetim altında, tüm canlılar arasında adaletli şekilde paylaşımını amaçlayan bu etik kuralı israfları önlemeyi hedeflemektedir. Bir başka deyişle önceki iki etiğin gerçekleşebilmesi için gerekli ortam ve düzen için kararların belirlenmesidir.

Permakültür ilkeleri son çeyrek asırda çeşitli şekillerde tanımlanmıştır. İlkelerinin amacı ekolojik ve sürdürülebilir sistemlerin organizasyonu ve geliştirilmesi konusunda tasarımcılara yol göstermesidir. Illkeler, sürdürülebilir sistemlerin hem fiziksel hem de bilginin bütüncül ve kavramsal çerçevesini kapsamaktadır. Mollison'un "Permaculture a Designers Manual" (1979) ve "Introduction to Permaculture" (1981) ile Holmgren'in "Principles and Pathways Beyond Sustainability" (2001) kitabında tanımladığı başlıklar bu ilkelerin öne çıkan ve kabul gören tanımlamaları olmuştur. İki araştırmacının çalışmalarında yer verdiği ilkeler bu çalışmada biraraya getirilerek aşă̆ıda açıklanmaktadır (Şekil 2).

\subsubsection{Gözlem ve etkileșim kurma}

Permakültürde doğa ve insan ilişkisinin kalıcı olması, bu ilişkinin doğru tasarım kararlarıyla kurulmuş olmasına bağlıdır. Bu doğru tasarım kararları doğal alanlarda dikkatli gözlem ve etkileşim kurma ile elde edilebilir. Gözlem; permakültür ilkelerinde en önemli maddelerden biridir (Nolasco, 2012) çünkü; permakültür tasarımında uygulanan her şey doğanın döngüsünün ve insanın ihtiyaçlarının uyumlu bir şekilde sürdürülmesi esasında gelişmektedir. Gözlem ve etkileşim kurma ilkesiyle; doğal sistemde, insan intiyaçları sürdürülebilir bir şekilde karşılanabilecektir. Aynı zamanda araziye uygun tarımsal veya işlevsel sistemlerin gelişimi de gözlem ve etkileşim kurma ilkesine dayanmaktadır. Bu ilke kapsamında permakültür; eğim, rüzgar yönü, yağış rejimi gibi doğal özelliklerin dikkate alınmasına, ya da yağmur suyundan faydalanmak gibi konulara vurgu yapmaktadır.

\subsection{2. İşlevler arası ilişkilerin etkin düzenlenmesi}

Bu ilke tasarım alanında enerjinin planlanması ile ilgilidir. Diğer bir deyişle, enerjiyi en verimli şekilde kullanmak için ağaçlar, bitkiler, hayvanlar ve binalar gibi elemanların nasıl organize edilmesi gerektiği konusunu içermektedir (URL-2). Bu doğrultuda permakültür tasarımı alanındaki elemanların ne sıklıkta kullanıldıkları ve sağladıkları işleve göre yerleştirilmeleri enerjiyi etkin kullanma ilkesine dayanmaktadır Alanın doğal özelliklerine göre yapılan bu etkin enerji kullanımı organizasyonuna örnek olarak; yeşillik bahçesi gibi işlevlerin yerleşim alanına yakın, gıda ormanları (meyva ağaçları) gibi alanların ise yerleşmeden uzakta bir yere konumlandırılmaları verilebilir.

\subsubsection{Enerjiyi depolama}

Insanoğlunun vazgeçemeyeceği tüketim konusu, enerji kaynaklarının bilinçsiz ve aşırı kullanımına dayanmaktadır (Frank, 2015). Bu nedenle enerjinin depolanması, tasarım alanlarında büyük önem ifade etmektedir. Bu doğrultuda yenilebilir enerji üretimi, depolanması ve en verimli şekilde kullanılması için çalışmalar yürütmektedir. Diğer yandan enerji kullanımını azaltabilmek için doğa ve insan arasında dengeli bir etkileşim kurmayı amaçlamaktadır. Permakültür, sistemin devamlıı̆ı̆ı sağlamak ve daha fazla enerjiyi depolamak için enerjiyi en doğru şekilde kullanmayı hedefler.

\subsubsection{Verim alma}

Permakültür tasarım alanlarında, doğayla iç içe olan insanın doğadan karşılıksız olarak sağlayacağı en büyük katkı, ondan verimli bir şekilde faydalanmasına dayanmaktadır. Doğada verimli olarak kullanılan her yapıtaşı, sistemi daha sürdürülebilir ve daha çok ihtiyacı karşılayabilecek şekilde 
olmasını sağlayacaktır. Örneğin; tasarım alanında faydasız süs bitkileri yerine, yenilebilir ve kullanışı bitkilerin kullanılması yerin doğal koşullarına özgü daha verimli bir alan yaratabilmektedir. Bu süreçte insan ve doğa arasındaki etkileşimin doğru şekilde kurgulanması gerekmektedir.

\subsubsection{Geri bildirime dayanarak kendi kendini yöneten sistemler kurma/}

Geri bildirim, mevcut durumu düzenlemeye yarayan en büyük kaynaktır. Birden çok bileşenin biraraya getirilmesiyle oluşturulan permakültür tasarımı, kendi kendini düzenleyebilen sistemlere dayanmaktadır (Frank, 2015). Bu ilke, tasarım alanlarına sürekli olarak dış denetimle müdahale edilmesi yerine, sistemin kendi kendini düzenleyen yönünü ele almaktadır. Çevreden gelen geribildirimlerin değerlendirmesi, sistemin sürdürülebilirliği ve verimliliğini sağlayacaktır.

\subsubsection{Yenilenebilir kaynakları değerlendirme}

Doğa insanların, doğal yollardan enerji ihtiyacını karşılayabilmesi için fırsatlar sunmaktadır. Bu nedenle permakültür tasarımı, insanın enerji ihtiyacını karşılaması için yenilenebilir enerji kaynaklarının kullanımı teşvik etmektedir (Pick , 2017). Bu bağlamda sürdürülebilir bir doğal yaşam alanın oluşumu için yerin koşullarına göre güneş, rüzgar ve yağmur gibi yenilenebilir enerji kaynaklarının etkin şekilde yönetilmesi ve sürdürülmesi vurgulanmaktadır. Örneğin güneş enerjisi ısı ve elektrik üretiminde, rüzgar enerjisi su pompalamak ve elektrik üretiminde, yağmur suyu ise sulama dahil birçok ihtiyaç için kullanılabilmektedir. Yağmur suyunun tasarım alanlarında toprak kirliliğini önleme, ısı etkisinin azaltırılarak mikroklimayı olumlu yönde etkilemesi gibi faydaları bulunmaktadır. Yağmur suyunu toplamadaki amaç, yağmurdan en iyi şekilde faydalanıp sistemdeki su akışını yavaşlatmaktadır. Bu doğrultuda bitki örtüsü ne kadar zengin olursa suyun depolanma olasılığı da o kadar fazla olmaktadır.

\subsubsection{Uygun teknolojiyi kullanım}

Uygun teknoloji, permakültürdeki çevre dostu sistem ve ekipmanların kullanımını tanımlamaktadır. Uygun teknoloji, güneş veya rüzgar gibi yenilenebilir enerji kaynaklarının yanısıra, düşük enerji gereksinimine sahip veya atık ve kirlilik üretmeyen bir teknoloji kapsamaktadır. Bu bağlamda küçük ölçekli, pratik, enerji açısından verimli, kirlilikten arındırımış, çevre bakımından duyarlı ve yerel kaynak açısından egemen olan teknolojiler, permakültürün tercih etiği kriterlerdir (Childs, 2004). Ayrıca tasarım alanında uygulanacak çalışmalar, tasarım alanının kendine has özelliklerine uygun olarak seçilmelidir. Örneğin; tasarım alanının coğrafik konumu, iklimsel durumu gibi bilgiler, üretilecek veya kullanılacak enerjinin tipini, kullanım şeklini, depolama yöntemini belirleyen bir etken olabilmektedir. Sulama sistemleri bu ilke kapsamında verilebilecek örneklerden biridir (Şekil 3). Bu bağlamda damlama, sulama, artıma sistemleri ile hem yağmur hem de banyo ve duştan gelen gri suların tekrar değerlendirmesini mümkün kılmaktadır.

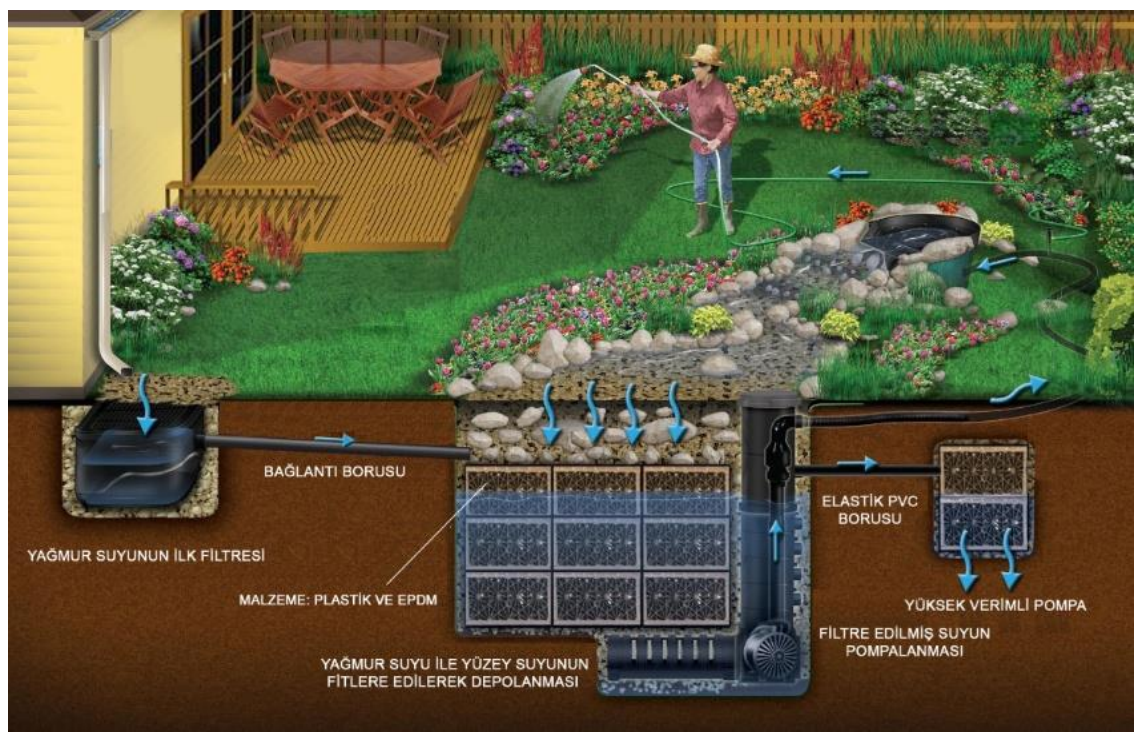

Şekil 3. Sulama için kullanılan sulama teknolojisi (URL-3). 


\subsubsection{Atık üretmeme}

Doğanın kendi içinde atık diye bir kavram bulunmamaktadır. İnsan faktörünün girdiği, doğadışı olan sistemler atık meydana getirmektedir. Mollison (1979)'a göre, sistem içerisindeki kaynaklar verimli bir şekilde kullanılmadıklarında sistemin kirlenmesine sebep olmaktadırlar. Permakültür tasarımında, bir sistemde meydana gelen atıklar başka bir sistemde kaynak olarak kullanılırsa hem doğanın başka aşamalarına girdi olarak aktarılmış olur hem de doğanın kendi tabiatına uygun bir işleyiş gerçekleşir. Dolayısıyla çöp diyerek attığımız çoğu atık doğaya geri kazandırılabilir özelliklere sahip olabilir. Örneğin; bitkisel kaynaklı atıklar toprak için organik ve doğal gübre ihtiyacını karşılayabilmektedir. Buna göre atıkların doğaya tekrar geri dönüştürülmesi sürdürülebilir bir çevrenin oluşumunu mümkün kılmaktadır. Örneğin; çöplerde oluşan metan gazından elde edilen ısı ve enerji ile, insanların ısınma ve elektrik ihtiyacı karşılanabilmektedir. Böylece metan gazı çevre için bir tehditten ziyade, değerlendirebilir bir kaynağa dönüşmektedir.

\subsubsection{Tekrar eden detaylara göre tasarım yapma}

Permakültür tasarım ilkelerinin doğadaki tekrar eden detaylara göre belirlenmesi, hem uygulamanın doğayla uyumlu olması hem de sürdürülebilir bir sistem oluşturulmasını sağlayabilmektedir. Doğada bulunan her detay belli bir görevi üstlenmektedir. Bu detayların ifade ettikleri doğru şekilde anlaşılabilirse tasarım süreci için ana veya destekleyici kaynak olarak kullanılabilir (Shein, 2013). Doğadaki çeşitli işlevsel birliktelikler, permakültür için daima bir esin kaynağı olmuştur. Bu bağlamda doğal yapıların değerlendirilmesi; enerji ve kaynakların verimli kullanılmasına da imkan sağlayacaktır. Örneğin, bitkilerin doğal ormanlarda olduğu gibi (ağaç, ağaççık çalı, yerörtücüler, otlar ve çiçekler vd.) uygun biçimde düzenlemesi, bitkilerin verimliliğini desteklemektedir (Şekil 4).

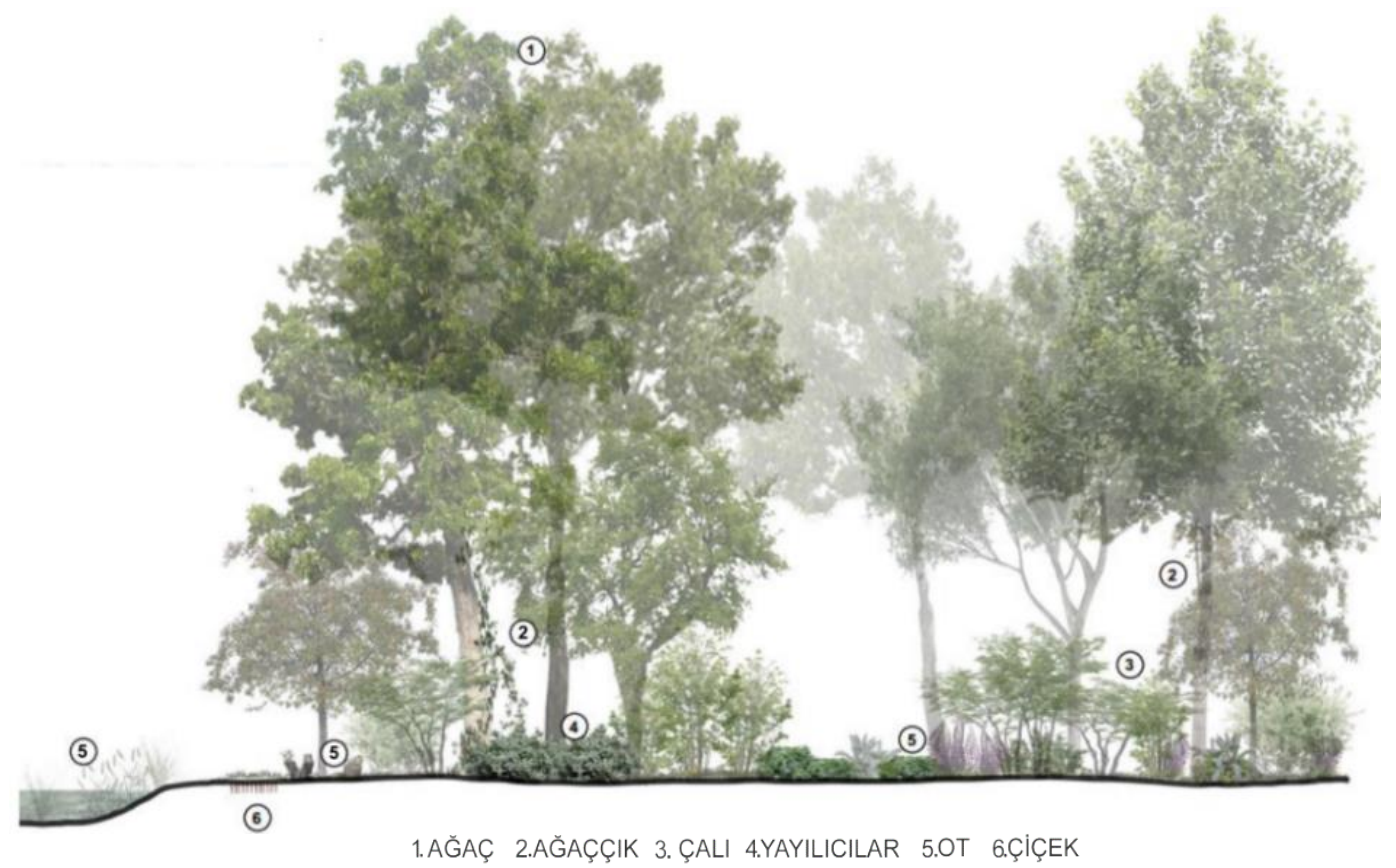

Şekil 4. Bitkilerin doğal ortamlardaki sıralanması (Hahn, 2014)

\subsubsection{Elemanları birleştirme}

Doğadaki her eleman belli bir görev üstlenmekte, aynı zamanda bulunduğu veya gerçekleştirdiği işlev ile başka bir elemanın ihtiyacının karşılamasına da olanak tanımaktadır (URL-4). Elemanlar arasındaki ilişkiler, doğadaki pozisyonlarına göre birbirleriyle bağlantılı olup, doğal ekosistemin gelişimine ve idame ettirilmesine katkı sağlamaktadır. Örneğin, bir ağaç bulunduğu ortamda hem canlıların besin ve oksijen kaynağı hem de erozyondan korunmaya katkı sağlayan bir bileşen olabilir (Şekil 5). Ya da toprakta bulunan ayrıştırııılar topraktan kendi besinlerini karşılarken diğer yandan toprakta bulunan besin maddelerini bitkiler için kullanışlı hale getirmektedir. 


\subsubsection{Küçük ve yavaş çözümler kullanma}

Permakültür tasarımlarında eylemler, alanın büyüklüğü ve yerel koşullar gözönünde bulundurularak küçük ve yavaş çözümlerle uygulanmalıdır. Sistemin öncelikle en küçük ölçekteki işlevini yerine getirmek üzere tasarlanan alanlar daha verimli ve sürdürülebilir olmalıdır (Althouse, 2016). Bu bağlamda küçük ve yavaş çözümlerin uygulandığı alanlar daha kalıcı değişimlerin oluşumunun yanısıra, tasarım alanını tehditlere karşı daha dayanıklı kılmaktadır. Bu ilke kapsamında permakültür, küçük ölçekli, bilinçli çözümlerin önemini vurgulamaktadır. Küçük ve yavaş çözümlere; bitkileri doğal yöntemlerle gübrelemek, topraktaki nemi muhafaza etmek, toprak sıcaklı̆ıını düzenlemek, sulama ihtiyacını azaltmak ve suyun toprakta hızlı süzülmesini önlemek gibi eylemler örnek verilebilir.

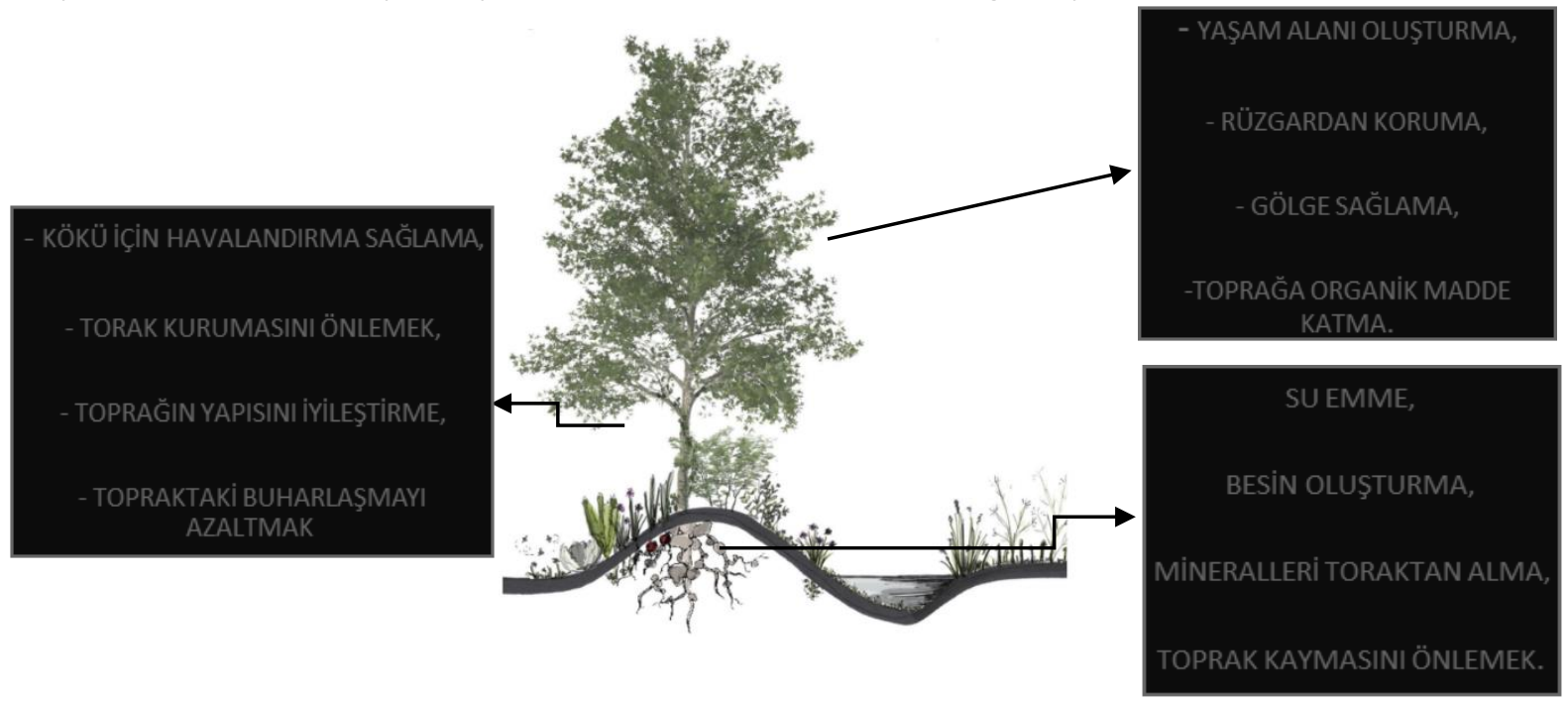

Şekil 5. Doğadaki elemanların etkileşimli bağlantısı (Hahn, 2014)

\subsubsection{2. Çeşitliliği sağlama ve artırma}

Bir tasarım alanının doğal, kalıcı ve sürdürülebilir gelişmesi, canlı çeşitliliğinin artışıla ilgili etkileşime bağlıdır. Bu ilke sayesinde sistemdeki çeşitlilik ve üretkenliğin artması amaçlanır (Mollison, 1981). Böylece doğa, dış tehditlere karşı daha savunmacı bir tasarım alanı olma özelliği kazanmaktadır. Bu kazanım, çeşitlilik sayısına bağı olmanın yanında canlıların birbiriyle olan ilişkisine de bağlıdır. Dolayısıyla bu ilkenin savunduğu konu, türlerin fazlalığından ziyade, türler arasındaki vararlı ilișkilerin

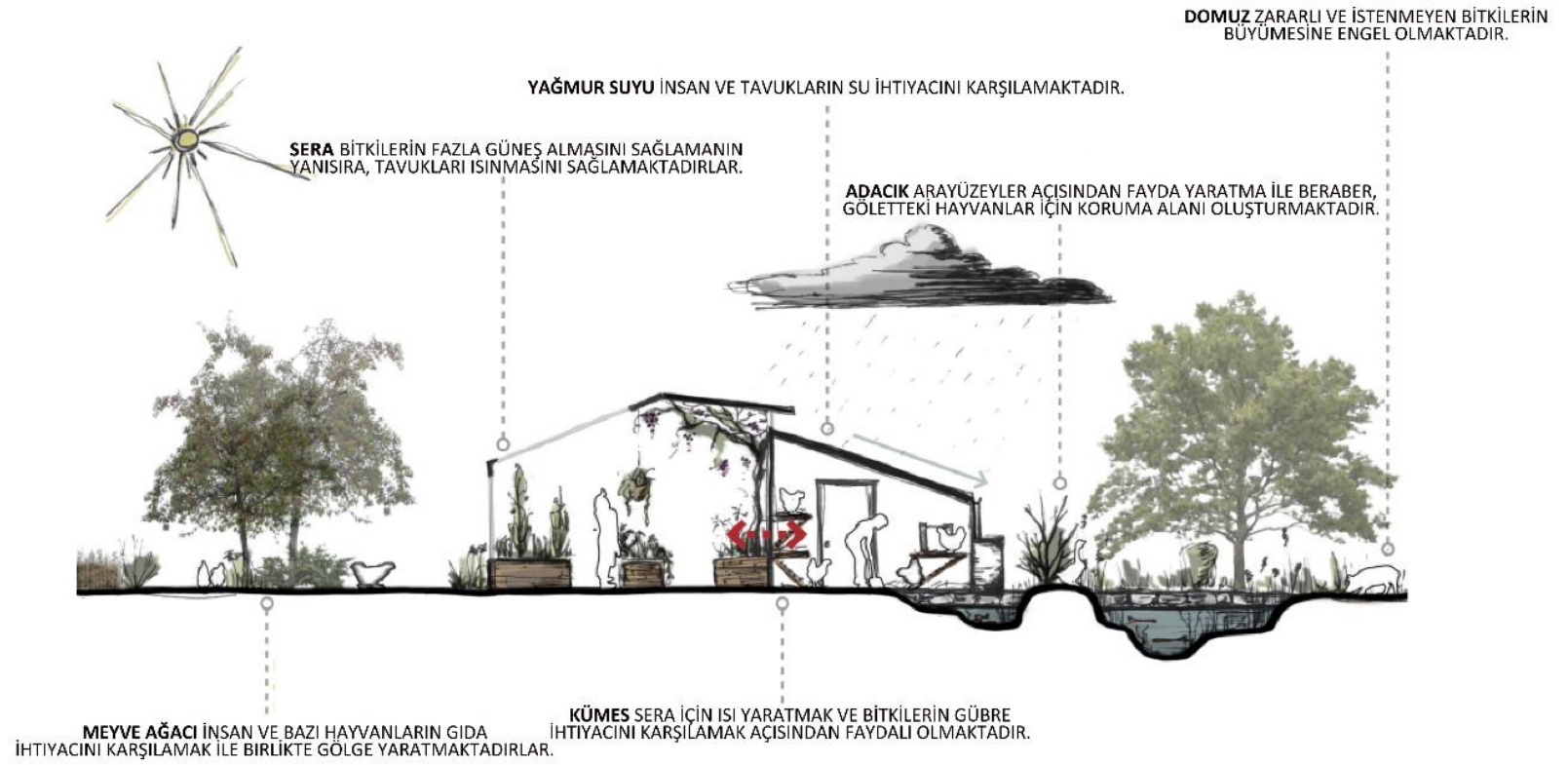

Şekil 6. Tasarım alanındaki yararlı ve işlevsel ilişkiler (Hahn, 2014) 


\subsubsection{Arayüzeylerden faydalanma ve marjinal değer edinme}

İki farklı değere ve özelliğe sahip ortamların biraraya getirilerek birbirilerini tamamlamasıyla oluşan doğal alanlar, tekil olarak tasarlanmış alanlara göre daha fazla sayıda canlının yaşamasını sağlama ve daha verimli sistemlerin oluşmasını desteklemeye yardımcı olmaktadır (Francis, 2007). Bu ilke, sistemdeki güçlü yönlerin genişletilmesi ile sistem verimliliği ve istikrarı artırabileceği fikrini içermektedir. Arayüzeylerden faydalanma, permakültür tasarımının başlıca önemli özelliklerinden birisidir. Permakültür açısından arayüzeylerde bulunan unsurlar arasında karşılıklı yarar sağlayan daha fazla sayıda ilişki bulunmaktadır. Örneğin; tarla ve gölet arasındaki arayüzeylerin ilişkilendirilmesi, her iki ortamın da verimliliğini artırabilme potansiyeli taşımaktadır.

\subsubsection{Değişime yaratıcı şekilde yanıt verme}

Permakültür; doğal yaşam sistemleri ve insan kültürünün dayanıklılığı için, esneklik ve değişime büyük ölçüde bağlıdır. Doğada meydana gelebilen bu değişimlere; yaratıcı, bilinçli ve işbirliği içerisinde yanıt verilmesi gerekmektedir Sistemde meydana gelen temel ve yüzeysel değişiklikler, sistemin daha kararlı olmasını sağlamaktadır. Toprağın iyileştirilmesi için hızlı büyüyen ve nitrojen içeren ağaçlarının kullanılması bu ilkeye örnek olarak verilebilir.

\subsubsection{Bileşenlere işlev kazandırma}

Bir elemanın birden çok işleve sahip olması permakültür tasarım alanları için önemli bir özelliktir. Tasarımın sürdürebilir olması için önemli olan bu ilke, bir sistemde yaşanılan herhangi bir olumsuzluğun, sistemin bütününü etkilemesini önlemektedir. Bu bağlamda permakültür, bir ortamın tasarımında kullanılan her bileşenin birden fazla işleve sahip olmasını vurgulamaktadır. Birden çok bileşenin birbirleri arasında oluşan işlevsel bağlantı daha denge odaklı bir sistem oluşturmaktadır. Örneğin, bir gölet; manzara, rekreasyon alanı sağlama, sulama potansiyeli barındırma, mikroklimayı dengeleme ve yaşam alanı yaratma gibi işlevleri yerine getirmektedir (Şekil 7).

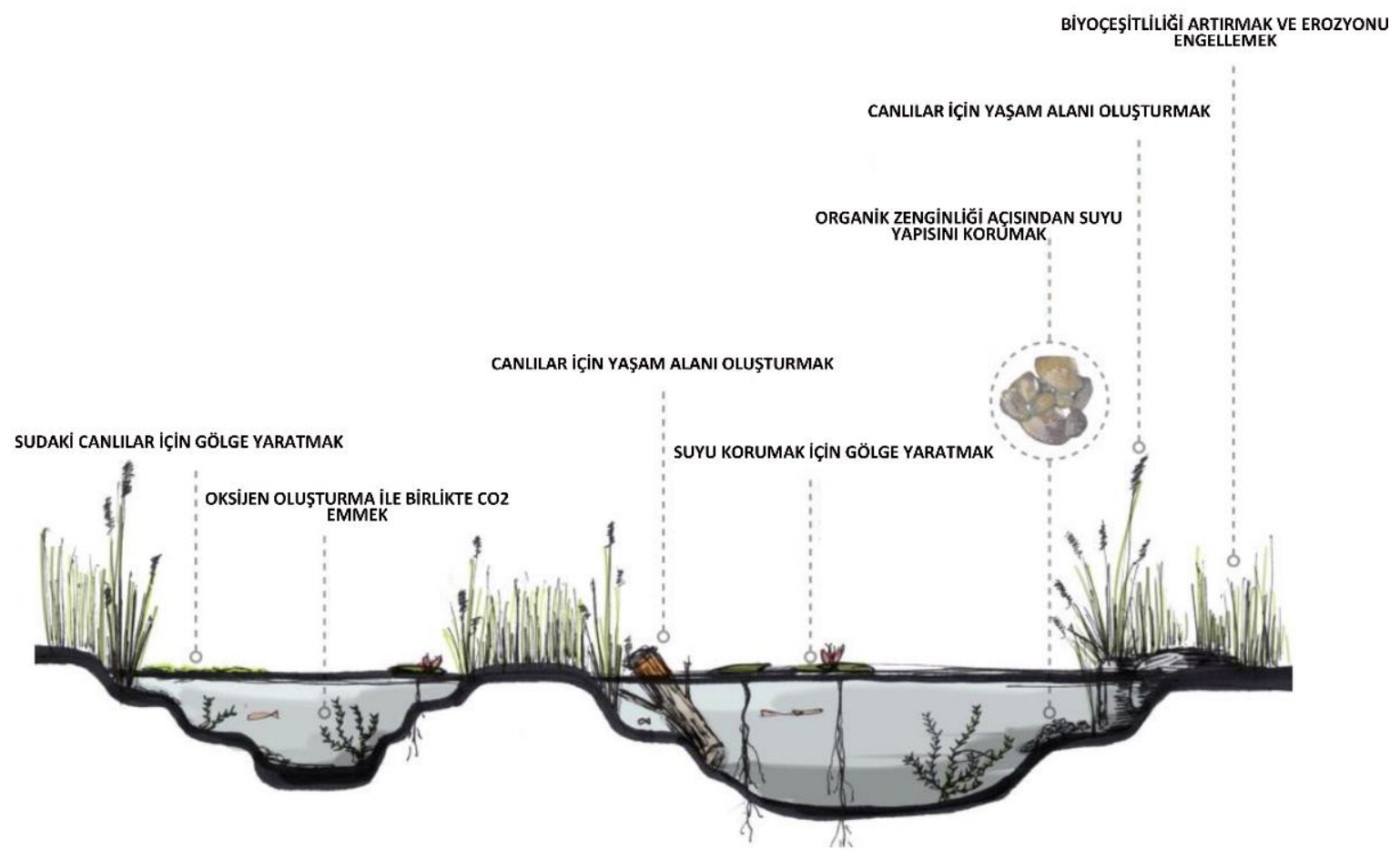

Şekil 7. Bir göletteki bileşenlerin işlevselliği (Hahn, 2014)

\subsubsection{6. Önemli işlevlerin desteklenmesi}

Tasarım alanlarında önemli işlevlerin birden çok bileşen/eleman tarafından desteklenebilir olması gerekmektedir (Hemenway, 2015). Permakültür, birden fazla bileşen tarafından desteklenen bu işlevleri bireysel olarak değerlendirmek yerine, bileşenlerin kendi aralarında bağlantılar kurarak daha güçlü bir sistem ve topluluğun oluşmasını hedefler. Dolayısıyla, herhangi bir aksilik anında o aksiliği bertaraf edecek veya bir alternatif sunacak bir sistem bulunması mümkün olmaktadır. Örneğin; 
tasarım alanında sulama sistemi devre dışı kaldığı takdirde yağmur suyu depoları gibi alternatif bir sulama sisteminin devreye girmesi tasarım alanındaki işleyişin sürekliliğini sağlayacaktır.

\subsection{Permakültür Tasarım Aşamaları}

Permakültür aşamaları yukarıda açıklanan ilkelerle birlikte tasarımcıya bir yöntem sunmaktadır. Permakültür, insan ve doğayla olan ilişkisinin faydalı şekilde sürdürülmesine dayalı bir yer bilimi olduğundan, bu etkileşimin uzun vadede yapıcı sonuçlar verebilmesi aşamaların uygulanmasına bağlıdır. Mollison (1979)'un sekiz adımdan oluşan permakültür tasarım aşamaları aşağıda verilmektedir (Şekil 8).

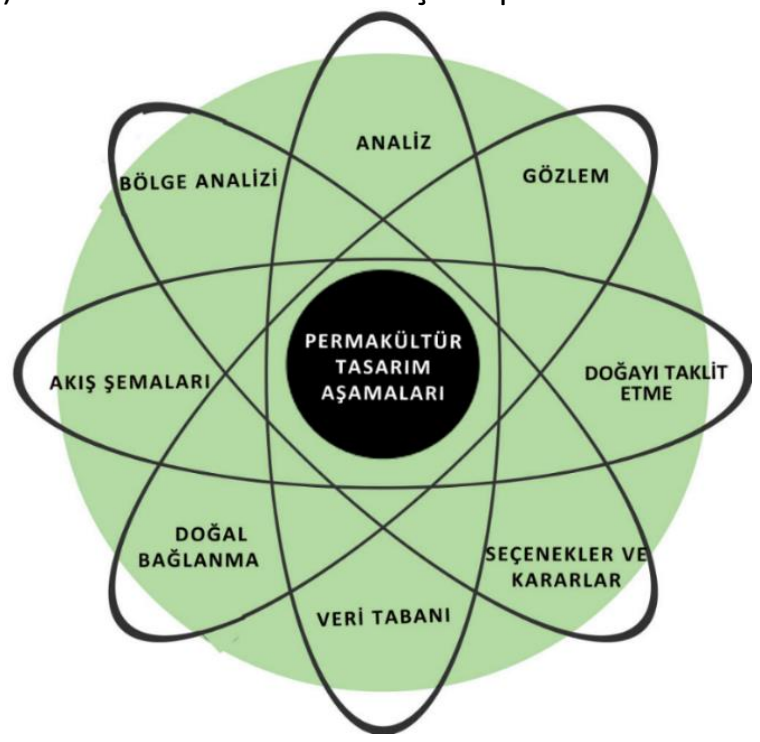

Şekil 8. Permakültür tasarım aşamaları (Najafidashtape, 2017)

Tasarım süreci öncelikle analiz çalışmasıyla başlamalıdır. Tasarım hedefleri doğrultusunda uygulama alanında bulunan canlı-cansız tüm elemanların neler oldukları ve bu elemanların görev ve ihtiyaçları belirlenmeli, buna ek olarak elemanlar arasında verimli bağlantılar kurulmalıdır. Bunun gerçekleştirilebilmesi için tasarım alanındaki tüm elemanların gözlemlenmesi; alanın coğrafik, ekolojik, kültürel ve tarihsel nitelikleri bakımından incelenmesi etkileşimlerin tespiti açısından işe yarar sonuçlar vermektedir. Gözlemler sonucu elde edilecek etkileşimler tasarım alanında bulunan ya da kullanılan elemanların kendi kendini düzenleyecek şekilde konumlandırılmasında yol göstermektedir.

Doğal sistemlerin inşa süreçlerini esas alan doğayı taklit etme aşamasında uygulamaların; ekosistemlerin çeşitliliği, istikrarı ve esnekliği doğrultusunda tasarlanması amaçlanmaktadır (URL-5). Doğayı taklit etme yöntemi ile insanların intiyaçları, doğaya karşı olarak değil, doğayla yandaş bir etkileşim çerçevesinde sağlanmalıdır. Bu sayede enerji ve malzeme tasarrufu ile doğada yeterlilik ve devamlılık oluşturulmalıdır.

Seçenekler ve kararlar üreten insan, doğaya uygun bakış açısıyla sistemin sadece bir parçasına değil bütününe odaklanmalıdır. Belirli etik kuralları çevresinde tasarlanan alandaki elemanlardan birinin neden olduğu olumlu ve olumsuz bir çıktı, doğal döngü içinde başka bir elemanın gelişim sürecini ya da aşamasını olumlu yönde etkileyebilir (URL-6). Bu nedenle ihtiyaç ve hedefler doğrultusunda kararlar alınırken, belli bir alanda meydana gelen bir sorunun, başka bir alanın ya da elemanın ihtiyacının karşılanmasında değerlendirilmesi gözetilmelidir.

Toplanan veri tabanına göre tasarım alanının özelliklerini haritalamak tasarım alanının temel ve kalıcı özelliklerini gösteren çizimler elde edilmesini sağlar. Çizimler tasarlanan alanların her yönden değerlendirilmesi, analizi, bitki örtüsünün durumu ve konumlandırılma özellikleri gibi birçok veriyi içermektedir (URL-7). Bu harita farklı plan ve çizimler arasındaki ilişkiyi inceleme amaçlı kullanılmaktadır. 
Permakültür uygulamasının gerçekleştirildiği alanda insan, doğa ve diğer canlıların sahip olduğu öznel özelliklerine göre elemanlar arasında doğal bağlantı sağlamak sistemin daha sürdürülebilir ve güvenli bir tasarım olmasını sağlayacaktır. Her öznel bağlantı, sistemin daha farklı ve doğal olması demektir.

Tasarım aşamalarına göre tasarım fikirlerini içeren akış şemaları, alanın ayrıntılarını içeren haritalar olarak nitelendirilebilir. Bu haritalar, daha sonra üretilen fikirlere yol gösterici ve tasarım alanının tüm özelliklerini pratik biçimde incelemeye yaramaktadır. Alan analizi ve değerlendirme yapmak ise, hem insan gücünü hem de doğanın sahip olduğu yetkinliklerin en etkin ve verimli şekilde kullanıımasını sağlamaktadır. Mollison (1979)'a göre bölge analizi; elemanların, kullanım yoğunluğuna ve yönetimine dayanan unsurlara göre organize edilmesidir. Örneğin; yapılan analizler neticesinde enerji tasarrufu konusunda tasarımın verimli olarak işlemesi için yerleşimler tasarlanabilir.

\subsection{Permakültür Örnekleri}

Paradise Lot bir dönümlük alan büyüklüğündeki Amerika Birleşik Devletleri'nin Massachusetts kentinin Holyoke bölgesinde kurulan bir çiftliktir. 1990 yılından buyana permakültür uygulamalarının yapıldığı bu çiftlikte yerli bitkilerin yanısıra, dünyanın dört bir yanından gelen faydalı bitki türleri de yetiştirilmektedir. Ayrıca su ürünleri yetiştiriciliği ve hayvancılık da yapılmaktadır. Bu permakültür uygulamasında; geri bildirime dayanarak kendi kendini yönetme, çeşitliliği sağlama, küçük ve yavaş çözümler kullanma gibi permakültür ilkeleri gerçekleştirilmektedir (Şekil 9). Burada yürütülen permakültür faaliyetlerinin hedefleri arasında; elde edilen deneyimlerin paylaşımı ve tasarım yöntemleri konularında insanları bilinçlendirmek, faydalı bitkilerin yetiştirilmesi, sağlıklı gıda üretimi konuları yer almaktadır.

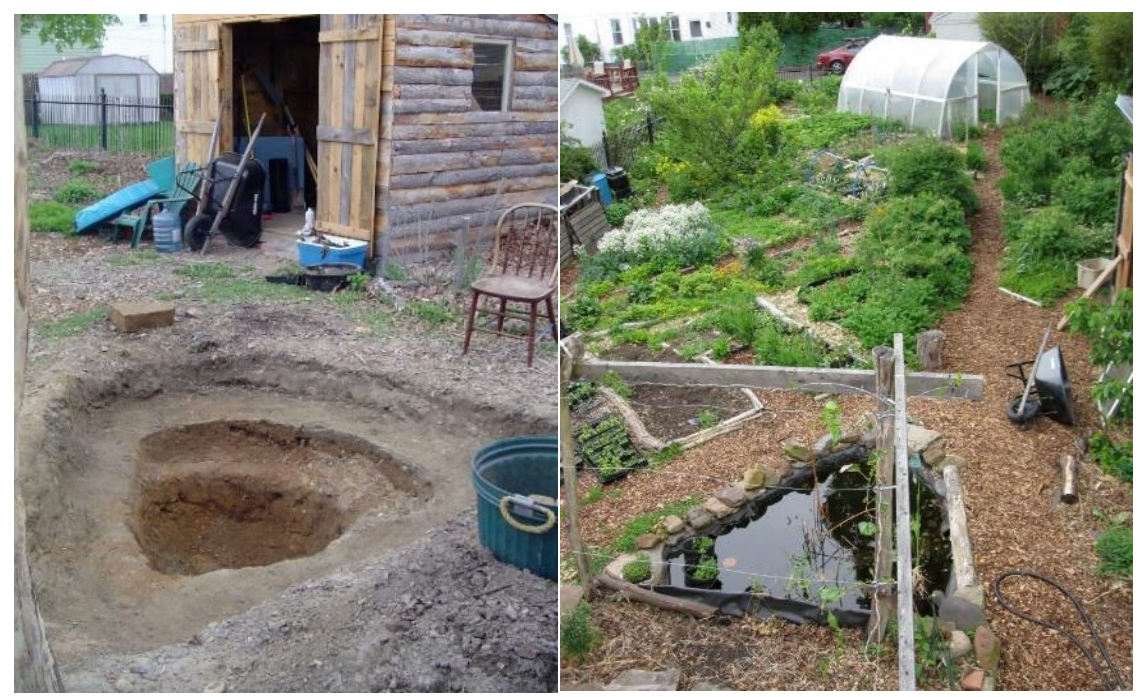

Şekil 9. Gölet tasarımı, Paradise Lot permakültür uygulaması (URL-8)

Glengall Wharf Garden Londra'nın merkezinde yer alan ve ılıman nemli Okyanus ikliminin hakim olduğu bir coğrafyada konumlanmaktadır. Yaklaşık bir hektar büyüklüğünde bir araziye sahip bu uygulama alanında gerçekleştirilen permakültür çalışmaları 2012 yılından beri yerel halkın katılımı ile sağlanmaktadır. Sürdürülebilir bir kamusal alan özelliği taşıyan uygulama alanında yenilenebilir bitki türleri yetiştirilmektedir. Bu çiftlikte permakültür ilkelerinden; enerjiyi depolama, biyolojik kaynakların kullanımı, yenilenebilir kaynakları değerlendirme ve değişime yaratıcı şekilde yanıt verme uygulanmaktadır (Şekil 10). Bu permakültür uygulama alanı; yerel toplumu canlandırma, sürdürülebilirlik konusuna katkıda bulunma, permakültür gibi ekoloji tasarımları destekleme ve sağıklı ürün yetiştirme gibi hedefler doğrultusunda kullanılmaktadır. 


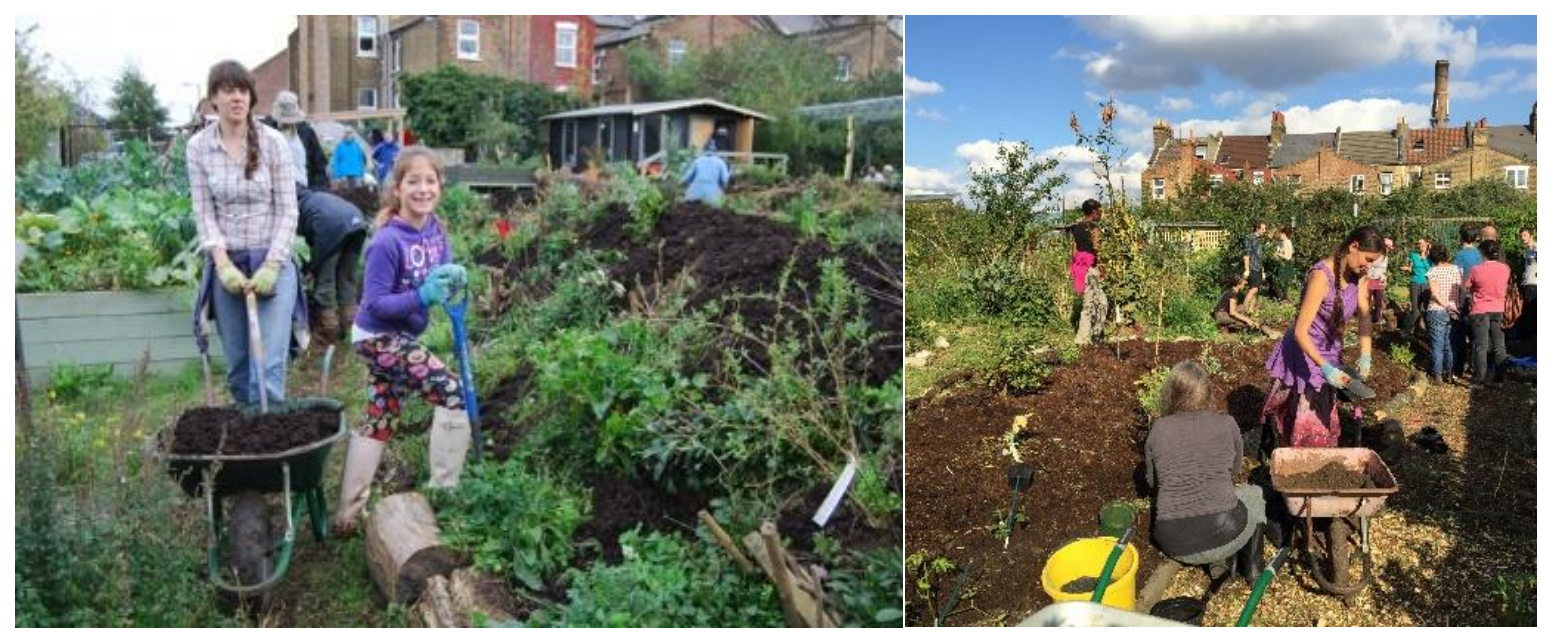

Şekil 10. Toprağın canlandırılması, Glengall_Wharf_Garden_permakültür uygulama alanı (URL-9)

The Urban Homestead, Los Angeles'da doğa dostu yaşam alanları yaratma hedefiyle 2003 yılından itibaren mülk sahibi tarafından evin ihtiyaçlarını karşılama amaçlı uygulamaya başlamıştır. Yaklaşık bir dönümdeki bu permakültür uygulaması, Los Angeles şehir merkezine yakın bir konumda yer almaktadır. Burada öne çıkan özellik, enerjinin güneş panelleri ile yenilenebilir bir şekilde temin edilmesidir. Bu projede enerjiyi depolama, yenilenebilir kaynakları değerlendirme, verim alma ve değişime yaratıcı şekilde yanıt verme gibi ilkeler benimsenmiştir. Permakültür uygulamasındaki hedefler arasında; doğal yaşam alanı yaratma, çevre sağlığını koruma, enerji konusunda tasarruf yapma ve sağııkı doğal sistemler kurma bulunmaktadır (Şekil 11).

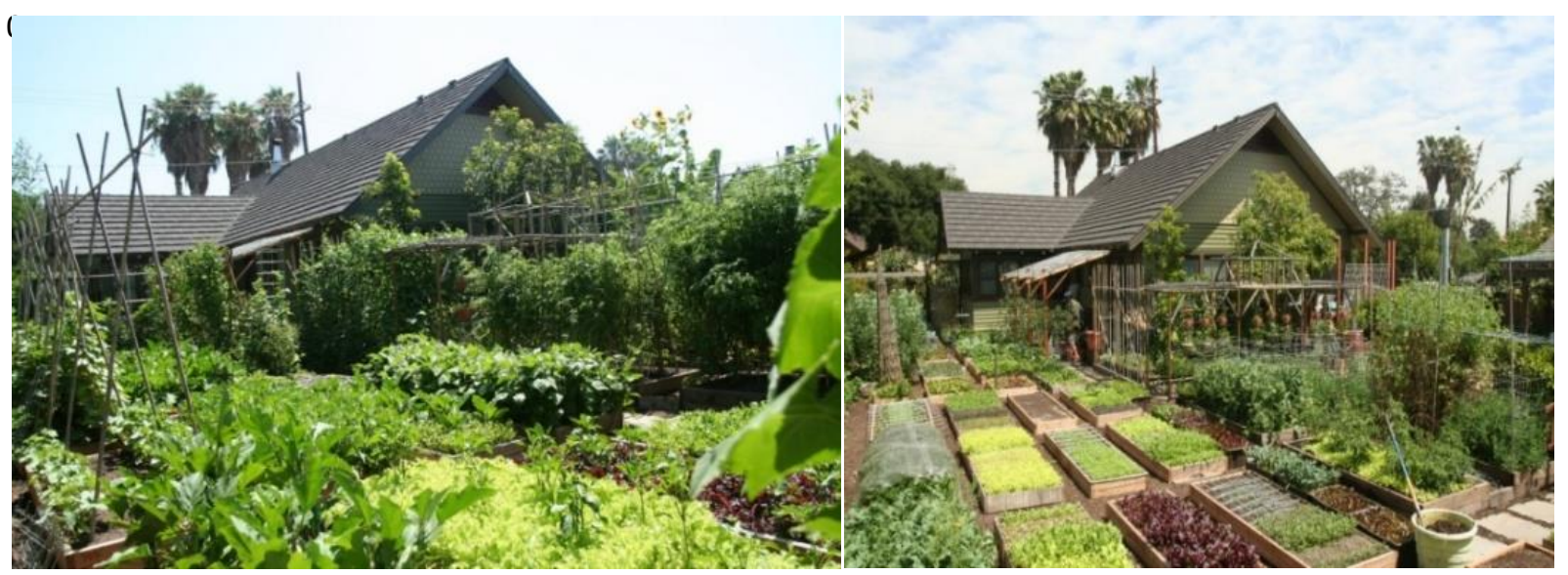

Şekil 11. Gıda ormanı tasarımı, The Urban Homestead permakültür örneği (URL-10)

Umass Amherst Akdeniz iklimine sahip Amerika Birleşik Devletleri'nin Amherst Üniversitesi'nde yer almaktadır. Kampüs içindeki bu alan bakımlı bir çim alanın otopark alanına dönüştürülme girişiminin yerine permakültür uygulama alanı olarak tasarlanması ile 2009 yılında oluşturulmuştur (Şekil 12). Üniversite öğrencilerinin katılımıyla düzenlenen bu alan yenilenebilir bitkiler üretebilecek bir arazi olarak tasarlanmıştır. Bu alanda permakültürün tekrar eden detaylara göre tasarım yapma, verim alma, gözlem ve etkileşim kurma ve değişime yaratıcı şekilde yanıt verme ilkeleri uygulanmaktadır. Üniversitede tüketilmek üzere besleyici gıdaların üretilmesi, kampüs topraklarında çevre sağlığının geliştirilmesi, öğrencilerin ürünleri tanıma ve ürün yetiştiriciliği konularında bilgilendirme ve eğitimin sağlanması bu uygulamanın hedefleridir. 


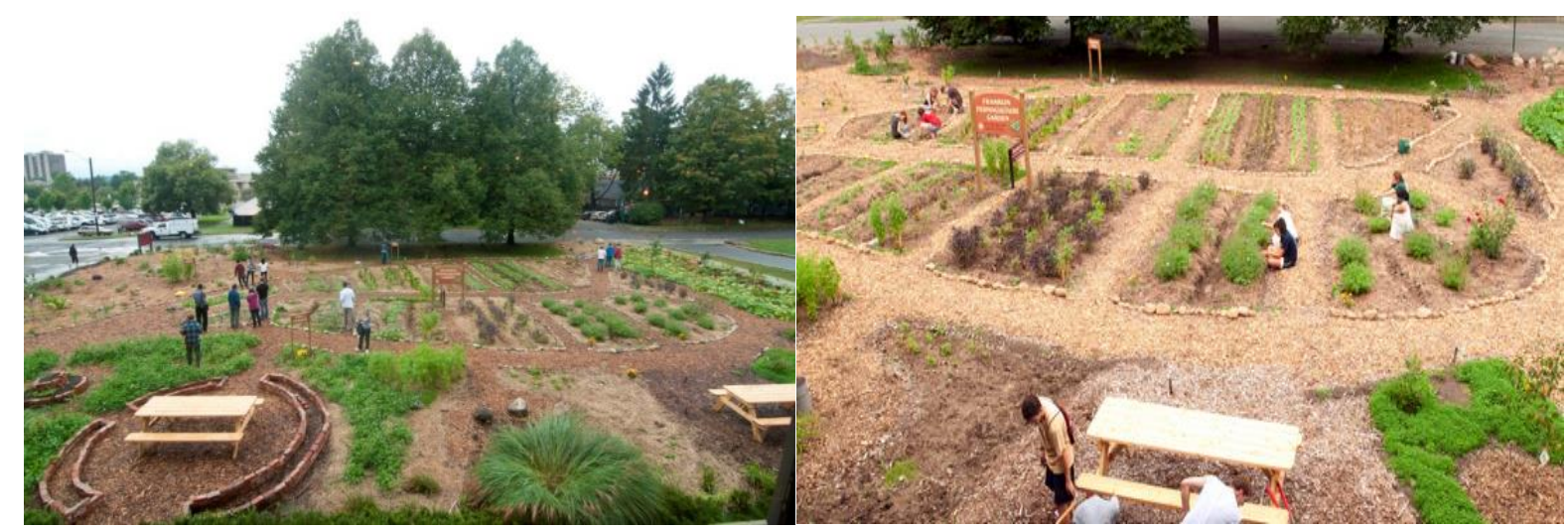

Şekil 12. Permakültür projesinin oluşturulması, Umass Amherst permakültür uygulama alanı (Hemenway, 2015)

\subsection{Permakültür Tasarımının Kentsel Açık ve Yeşil Alanlar Açısından Önemi}

Permakültür tasarımının uygulandığı alanlar; kendi enerjilerini üretebilmekte, doğal kaynaklarının sürekliliği bakımından geri dönüşüm sağlayabilmekte, kendi kendine yetebilmekte ve bulundukları çevreye yiyecek üretebilmektedir. Bu süreç; enerji verimliliği, yenilenebilir enerji kaynaklarının kullanımı, sağlıklı besin döngüsünün yaratılması, atıkların tekrar kullanımı, kimyasal katkıların kullanılmaması, toplumsal ve kültürel değerlerin korunması ve doğal yaşam alanlarının oluşturulması konularını içermektedir. Bu doğrultuda kentsel açık ve yeşil alanların permakültür ilkeleri ile sorumlu üretim ve tüketim anlayışı çerçevesinde tasarımının önemi;

- kentsel açık ve yeşil alanların yerin doğal koşulları ve özelliklerine uygun tasarlanması ve yönetiminin sağlanması,

- su, enerji gibi kaynakları israf etmeden, ihtiyacı azaltan, kendi içinde karşılayan ve değerlendiren yöntemler ile ele alınması,

- katı ve sıvı atıkların kendi sistem döngüsü içinde kullanılması ve geri dönüşümünü sağlayan çevre dostu yaklaşımların değerlendirilmesi,

- kentsel açık ve yeşil alanların nitelikli gelişip, geri beslenme fikri doğrultusunda, tasarım ve arazinin değerlendirilmesine yönelik nitelikli yöntemlerin geliştirilmesi,

- kentsel açık ve yeşil alanların toprak yani yumuşak yüzeylerin mümkün olduğunca korunması ve bu sayede yapılaşmış çevrelerin neden olduğu ısı adası etkilerinin azaltılması,

- toprağın bereketinin ve verimliliğini arttırılması,

- gıda konusunda tek bir ürün yerine dört mevsime yayılan çeşitli bitki ve ağaç türlerinin yetiştirilerek yerinde üretim ve tüketim olanağının sağlanması, bu sayede de kentlerde sistemin dışa bağımlıı̆ın azaltılması, karbon ayaz izinin ve hava kirliliğinin azaltılması ve uygun ücret karşılığında gıda teminin mümkün kılınması,

- kırsal alandan kentlere göç eden, özellikle tarım ve ürün yetiştiriciliği konusunda bilgiye sahip toplumun kesimlerine istihdam olanağının sağlanması,

- insanların toprakla uğraşarak üretici, rahatlamayı sağlayıcı faaliyetlerle sosyal açıdan dayanışmacı, güvene dayalı ilişkileri destekleyen ve deneyimlerin paylaşılabileceği doğal laboratuvar ortamlarının oluşturulması,

- gelecek nesillerin doğadan kopuk gelişimlerinin önüne geçilmesi ve bu bağlamda kentlerde çocukların bir yandan oyun oynayabileceği ama aynı zamanda ürünleri tanımasının sağlanması, doğanın döngüsü ve hatta bitki, ağaç, ürün yetiştiriciliği hakkında eğitilmesi, hassasiyetlerinin arttırılması,

- kentlerde doğal yaşam alanlarının devamlıı̆̆ının kurulması, biyoçeşitliliğin geliştirilmesi ve korunması için katkı sağlayabilen sürdürülebilir tasarımların irdelenmesi,

- olası afet ve iklim değişikliğine karşı kentlerin direncini destekleyecek sürdürülebilir çözümlerin geliştirilerek uygulanması gibi konular özelinde özetlenebilir. 


\section{Sonuç ve Öneriler}

Kentler insanlar için kültürel ve toplumsal unsurlarının egemen olduğu yerlerdir. Ancak günümüzde kentler karşılaştıkları çevresel ve fiziksel olumsuzluklardan dolayı, toplumun ihtiyaçlarını karşılayamaz hale gelmeye başlamıştır. Kentlerin bu sorunlardan arındırılması, insanların doğa ile olan ilişkisinin etkileşimli olmasına bağlıdır. Bu etkileşimin dengelenmesi açsından önem taşıyan açık ve yeşil alanlar, kentler için çevresel kalitenin artırılması ve toplumsal yapının güçlendirilmesi açısından, kentin altyapısını destekleyen temel alanlardır. Bu alanların sürdürülebilir olması kentin yaşanabilirliğini artırmak ile birlikte, fiziksel, çevresel ve ekonomik açısından da kent için katkılar sunmaktadır. Ancak günümüzdeki kentsel açık ve yeşil alanların tasarımında benimsenen süreç, hem doğa ve döngüsü konusunda hem de kentsel ihtiyaçları karşılama açısından yetersizdir. Bu durum; enerji israfı, kaynakların sağlıksız tüketimi ve doğal çevrenin kirlenmesi gibi olumsuzluklara yol açmaktadır. Bu nedenle kentsel açık ve yeşil alanların doğal niteliklerini destekleyecek ve sürdürülebilirliğini sağlayacak yöntemlerle tasarlanması gerekmektedir. Kentsel açık ve yeşil alanların kendi kendine yetebilir olması, kentlerin yaşanabilirliğini artırma ile birlikte kent ve çevresindeki kaynakların sağlıklı ve verimli bir şekilde kullanılmasını destekleyebilmektedir. Bu doğrultuda permakültür, son yıllarda doğadaki sağlıklı döngüye odaklanan ekolojik ve sürdürülebilir tasarımların bir parçası olarak gündeme gelmeye başlamıştır.

Permakültür, kentsel açık ve yeşil alanları ilgilendiren iklim, bitki örtüsü, canlılar, toprak ve su yönetimi ile insan ihtiyaçlarını entegre etmeye çalışan tasarım ve arazi kullanımına yönelik nitelikli bir yaklaşımdır. Permakültür tasarımı, bu alanları insanların ihtiyaçlarına yönelik düzenleme ve doğayı tahrip etmeden doğru şekilde faydalanmayı amaçlamaktadır. Incelenen uygulama örneklerinde görüldüğü üzere permakültür ilkeleri ve pratik tekniklerinin dikkate alınması, kentsel açık ve yeşil alanlardaki tasarımın sağlıklı gelişmesine olanak tanımaktadır. Bu süreçte permakültürün içerdiği ilke ve etikler, tasarımdaki her bir elemanın nasıl faydalı olabileceği ve hangi konumda nasıl değerlendirebileceği açısından katkı sağlamaktadır. Bu bağlamda permakültür ilkelerinden faydalanma, her bölgenin öne çıkan fiziksel ve yapısal potansiyelleri doğrultusunda ortaya çıkmaktadır.

Sonuç olarak permakültür, açık ve yeşil alanların daha sağlıklı, yaratıcı ve sürdürülebilir olmalarına yardımcı olacak teknikler ve ilkeler ortaya koymaktadır. Permakültür yöntemi benzersiz değildir, ancak dikkat edilmesi gereken önemli konu, permakültürün organik tarımdan farklı olmasıdır. Permakültürü diğer tasarım yöntemlerinden ayıran bir diğer özellik ise, bu tasarımın doğa ile insan yerleşimlerini bir bütün olarak tüm yönleriyle değerlendirmesi ve dolayısıyla düzenleyici olmaktan ziyade yaratııı olmasıdır. Permakültür, kentsel açık ve yeşil alanlar için, tasarım bileşenlerini bağlantılı bir şekilde yan yana getirerek tasarımın bir bütün olarak ele alınmasını sağlamaktadır. Ayrıca permakültür, kentsel açık ve yeşil alanların özündeki özellikleri kapsamlı bir şekilde ele alarak, bu alanların sağlıklı geliştirilmesi yönünde faydalı olacaktır. Bu bağlamda açık ve yeşil alanlarda permakültür tasarımı ile toprak ve doğal yaşam ilkesinin toplum hayatına tekrar kazandırılmasının yanısıra, insan ilişkilerinin günümüzde zayıf olduğu kentlerde toplum içindeki bağların ve değerlerin zenginleşmesini de sağlayacaktır.

Elde edilen sonuçlar doğrultusunda permakültür tasarımının uygulanması için yapılacak ilk çalışma, toplumsal bilinçlenmedir. Bu bağlamda tüketici bir yaşam biçimine alışmış insanların doğaya fayda sağlayacak çalışmaları, eğitim ve vizyon olmaksızın başarmak mümkün değildir. Diğer yandan yerel yönetimin bu gibi girişimlerin uygulanmasını desteklemesi önemlidir. Kentsel açık ve yeşil alanlarda permakültür uygulaması, bu tasarımın etik ve ilkeleri bağlamında sürdürülebilir ve etkin bir bakış açısıyla aşamalı olarak gerçekleşebilmektedir. Bu süreçte aşamaları kapsayan en önemli konulardan bazıları; yağmur suyunun toplanması, toprağın zenginleştirilmesi, yenilebilir ve uzun ömürlü bitki türlerinin alana dahil edilmesi, doğal ortamdaki bitki düzeninin (ağaç, ağaççık, çalı, yer örtücü ve kaplayıcılar) alanda uygulanmasıdır.

\section{Kaynaklar}

Althouse, K. (2016). An Instructional Module on Permaculture Design Theory for Landscape Architecture Students, Utah State University. 
Aydemir, S. E. (2004). Kentsel Alanların Planlanması ve Tasarımı, Akademi Kitabevi, Trabzon.

Bhatta, B. (2010). Analysis of Urban Growth and Sprawl from Remote Sensing Data, Chapter 2 Causes and Consequences of Urban Growth and Sprawl, Springer - International Publisher Science, Technology, Medicine.

Buchan, R. (2013). The Urban Farming Guidebook, Planning for the Business of Growing Food in BC's Towns \& Cities, Vancouver.

Childs, M, C. (2004). Squares: A Public Place Design Guide for Urbanists, University of New Mexico Press.

Frank, M. (2015). Permaculture 101: An Introduction to Regenerative Design, Dovetail Partners, INC.

Francis, R. (2007). Permaculture Design Course Handbook, Permaculture Education Djanbung Gardens PEC.

Hahn, E. (2014). A Permaculture Primer, Midwest Permaculture Presents.

Hall, P. (2011). Design for Social Sustainability, A Framework for Creating Thriving New Communities, London.

Hemenway, T. (2009). Gaia's Garden: A Guide to Home-scale Permaculture, 2nd Edition, Chapter Tree, Designing the Ecological Garden, Chelsea Green Publishing Company.

Hemenway, T. (2015). The Permaculture City, Regenerative Design for Urban, Suburban, and Town Resilience, Chapter One.

Holmgren, D. (2001). The Essence of Permaculture, Extracts of Book Permaculture: Principles and Pathways to Sustainability, Holmgren Design Services, The Source of Permaculture Vision and Innovation.

Hopper, L. J. (2007). Landscape Architectural Graphic Standards, Wiley Publishing.

Mabalay Flores, J. and Bosita Mendiola, R., L. (2016). Creating Virtual Corridors: Social Network Discovery and Landscape Patch Connectivity of Permaculture Projects, University of the Philippines Open University, Philippines.

Magigi, W. (2013). Urbanization and Its Impacts to Food Systems and Environmental Sustainability in Urban Space: Evidence from Urban Agriculture Livelihoods in Dar es Salaam, Tanzania. Journal of Environmental Protection, pp. ISBN: 4, 1137-1148, P. $1139-1142$.

Mensah, C. A. (2014). "Destruction of Urban Green Spaces: A Problem Beyond Urbanization in Kumasi City (Ghana)", American Journal of Environmental Protection, pp. Vol. 3, No. 1, P. 5-7.

Mollison, B. (1979). Permaculture: A Designers' Manual, Publishers for The Permaculture İnstitute, Second Edition.

Mollison, B. (1981). Introduction to Permaculture, Pamphlet I in the Permaculture Design Course Series Published By Yankee Permaculture.

Mollison, B. (2017). Permakültüre Giriş, Çevirmen: Egemen Özkan, Sürdürülebilir Yaşam Kitapları, Sineksekiz Yayınevi, İstanbul.

Nolasco, J. (2012). Sustainable Water Management for Urban Agriculture: Planting Justice, Oakland, Pacific Institute.

Pick, B. J. (2017). Renewable Energy, Problems and Prospects in Coachella Valley, California.

Rothe, K. (2014). Permaculture Design: On the Practice of Radical Imagination, Universität der Künste Berlin.

Shein, C. (2013). The Vegetable Gardener's Guide to Permaculture, Creating an Edible Ecosystem.

United Nations, (2004). World Urbanization Prospects: The 2003 Revision, Department of Economic and Social Affairs Population Division, New York.

The World Bank (2017). The United Nations Population Division's World Urbanization Prospects between 19602016, https://data.worldbank.org/indicator/SP.URB.TOTL.IN.ZS

Yavuz, C. (2017). Türkiye Büyük Bir Tehlike İle Karşı Karşıya: İklim Değişikliği, Yetersiz Beslenme ve Açlık Kapıda, HBT - Herkese Bilim Teknoloji Dergisi, Sayı.83, 27 Ekim 2017, ss.12-13.

Zeeuw, H. and Drechsel, P. (2015). Cities and Agriculture, Developing Resilient Urban Food Systems, London.

URL-1. http://www.geofflawtononline.com/about/, (Erişim Tarihi: 28 Eylül 2017)

URL-2. http://robertpermakultur.weebly.com (Erişim Tarihi: 28 Eylül 2017) 
URL-3. http://getpond.com/dont-be-fooled-capturing-rainwater-is-not-illegal-in-california (Erişim Tarihi: 5 Ekim 2017)

URL-4. https://deepgreenpermaculture.com/permaculture/permaculture-design-principles/2-eachelementperforms-many-functions/ (Erişim Tarihi: 6 Ekim 2017)

URL-5. http://www.small-farm-permaculture-and-sustainable-living.com/permaculture (Erişim Tarihi: 10 Kasım 2017)

URL-6. https://www.milkwood.net/2015/11/09/permaculture-design-process-2-making-a-base-map/

(Erişim Tarihi: 10 Kasım 2017)

URL-7. http://permateachers.eu/permaculture-design-process-7-design-drawing/ (Erişim Tarihi: 12 Kasım 2017)

URL-8. https://paradiselotblog.wordpress.com/about/ (Erişim Tarihi: 10 Aralık 2017)

URL-9. https://burgessparkfoodproject.org.uk/ (Erişim Tarihi: 10 Aralık 2017)

URL-10. http://urbanhomestead.org/ (Erişim Tarihi: 11 Aralık 2017) 